\title{
PELATIHAN PENGEMBANGAN KEPROFESIAN BERKELANJUTAN (PKB) BAGI GURU - GURU SE JAKARTA TIMUR
}

\author{
Agus Dudung \\ Fakultas Teknik Universitas Negeri Jakarta
}

\begin{abstract}
ABSTRAK
Tujuan Kegiatan ini adalah sebagai berikut:(1) meningkatkan kompetensi guru untuk mencapai standar kompetensi yang ditetapkan dalam peraturan perundangan yang berlaku. (2) Memutakhirkan kompetensi guru untuk memenuhi kebutuhan guru dalam perkembangan ilmu pengetahuan, teknologi dan seni untuk memfasilitasi proses pembelajaran peserta didik. (3) Meningkatkan komitmen guru dalam melaksanakan tugas pokok dan fungsinya sebagai tenaga profesional. (4) Menumbuhkan rasa cinta dan bangga sebagai penyandang profesi guru. (5) Meningkatkan citra, harkat, dan martabat profesi guru di masyarakat. (6)Menunjang pengembangan karir guru

Khalayak Sasaran dalam kegiatan ini adalah guru-guru yang akan membuat pengembangan keprofesian berkelanjutan ( $\mathrm{PKB}$ ) dalam rangka mengusulkan naik pangkat. Pada pelatihan ini direncanakan pelaksanaannya sebanyak 4 latihan pertemuan yang masing-masing selama 2 jam. Pada pertemuan pertama diberikan secara umum tentang pengembangan keprofesian berkelanjutan (PKB) dalam rangka mengusulkan naik pangkat. Pada pertemuan 2 sampai ke 4 latihan penerapan pembuatan proposal karya ilmiah dan pertemuan terakhir program kegiatan di adakan evaluasi.

Berdasarkan hasil pelatihan yang dilakukan, didapatkan beberapa kesimpulan. Antara lain:

(a) guru dapat memperkaya pengembangan keprofesian berkelanjutan (PKB). (b) guru dapat mengetahui bagaimana pelaksanaan pengembangan keprofesian berkelanjutan bertujuan untuk meningkatkan layanan pendidikan di sekolah dalam rangka meningkatkan mutu pendidikan (c) guru dapat mempercepat proses pembuatan karya tulis ilmiah dalam pengembangan profesi bagi guru. (d) guuru menjadi punyai keterampilan dalam membuat karya tulis ilmiah berdasarkan pada pengembangan profesi guru. (e) guru dapat meningkatkan kualitas penulisan ilmiah sebagai bahan untuk mempersiapakan kenaikan pangkatnya.
\end{abstract}

Kata kunci : Pengembangan keprofesian berkelanjutan

\section{PENDAHULUAN}

\section{Analisis Situasi}

Dalam rangka meningkatkan propesional guru dan diberlakukannya PERMENPAN dan Reformasi Birokrasi no. 16 Tahun 2009 tentang Jabatan Fungsional Guru dan Angka Kriditnya, maka setiap guru yang ingin menaikan pangkatnya diberlakukan untuk membuat Pengembangan Keprofesian Berkelanjutan (PKB). Dalam hal ini beberapa pertanyaan mendasar mungkin dapat kita ajukan seperti: (1) Apa yang dimaksud dengan profesi?; (2) Bagaimanakah guru profesional itu? Berkaitan dengan hal ini, karena guru sebagai suatu profesi maka dapatlah kita berasumsi bahwa guru seharusnya memiliki konsekuensi melakukan CPD (Continuous Professional Development) atau dalam istilah pemerintah Pengembangan Keprofesian Berkelanjutan (PKB). 
Pengembangan diri dalam PKB (Pengembangan Keprofesian Berkelanjutan) adalah upaya guru untuk meningkatkan profesionalisme diri agar memilki kompetensi sesuai dengan standar yang telah ditetapkan dan perkembangan pengetahuan, teknologi, dan/atau seni. Kegiatan pengembangan diri meliputi:

1. Diklat Fungsional Diklat Fungsional adalah kegiatan guru dalam mengikuti pendidikan atau pelatihan yang bertujuan untuk meningkatkan keprofesian guru yang bersangkutan dalam kurun waktu tertentu.

2. Kegiatan Kolektif Guru Kegiatan Kolektif guru adalah kegiatan guru dalam mengikuti kegiatan pertemuan ilmiah atau mengikuti kegiatan bersama yang dilakukan guru baik di sekolah maupun di luar sekolah (seperti IHT/KKG/MGMP, KKKS/ MKKS, dan asosiasi profesi guru) dan bertujuan untuk meningkatkan keprofesian guru yang bersangkutan.

Kegiatan kolektif ini dapat berupa :

a. lokakarya atau kegiatan bersama seperti IHT/KKG/MGMP,KKKS/ MKKS dan asosiasi profesi guru dalam menyusun perangkat kurikulum dan/atau pembelajaran;

b. keikutsertaan dalam kegiatan ilmiah seperti seminar, koloqium, diskusi panel, dan kegiatan ilmiah lainnya baik sebagai pembahas maupun peserta;dankegiatan kolektif lain yang sesuai dengan tugas dan kewajiban guru.

Adapun contoh kegiatan pengembangan diri yang dapat dilakukan dalam diklat fungsional maupun kegiatan kolektif guru antara lain sebagai berikut:

a. Penyusunan RPP, program kerja, perencanaan pendidikan, evaluasi, dansebagainya.

b. Penyusunan kurikulum dan bahanajar.

c. Pengembangan metode mengajar d. Pelaksanaan penilaian proses dan hasil pembelajaran peserta didik.

e. Pengembangan dan pemanfaatan teknologi informatika dan komputer (TIK) dalam pembelajaran.

f. Inovasi proses pembelajaran

g. Peningkatan kompetensi profesional dalam menghadapi tuntutan teori terkini.

h. Penulisan publikasi ilmiah.

i. Pengembangan karya inovatif.

j. Peningkatan kemampuan untuk mempresentasikan hasil karya.

Angka Kredit Kenaikan Jabatan Guru Terbaru, berlaku 1 Januari 2013. Aturan baru Angka Kredit bagi kenaikan Jabatan Guru ini akan berlaku efektif mulai tanggal 1 Januari 2013 dimana untuk kenaikan pangkat jabatan Fungsional Guru serendah-rendahnya Golongan III/b diwajibkan membuat Karya Inovatif berupa Penelitian, Karya Tulis Ilmiah, Alat Peraga, Modul, Buku, atau Karya Teknologi Pendidikan yang nilai angka kreditnya disesuaikan. Peraturan baru yang mengatur kenaikan pangkat jabatan fungsional guru (guru dan kepala sekolah) telah terbit ini dan ditetapkan berdasar:

1. Peraturan Menteri Pendayagunaan Aparatur Negara dan Reformasi

2. Birokrasi (PermenPANRB) No. 16 Tahun 2009 tanggal 10 November 2009 tentang Jabatan Fungsional Guru dan Angka Kreditnya.

3. Peraturan Bersama Mendiknas dan Kepala BKN Nomor 03/V/PB/2010

4. dan Nomor 14 Tahun 2010 tanggal 6 Mei 2010 tentang Petunjuk Pelaksanaan Jabatan Fungsional Guru dan Angka Kreditnya.

5. Peraturan Menteri Pendidikan Nasional Nomor 35 tahun 2010 Tentang

Petunjuk Teknis Pelaksanaan Jabatan Fungsional Guru dan Angka Kreditnya. Perhatikan pada golongan berapa Bpk/Ibu saat ini :

1. III/a ke III/b wajib melaksanakan kegiatan pengembangan diri (pelatihan 
dan kegiatan kolektif guru) yang besarnya 3 angka kredit.

2. III/b ke III/c wajib melaksanakan kegiatan pengembangan diri (pelatihan dan kegiatan kolektif guru) yang besarnya 3 angka kredit dan publikasiilmiah/karya inovatif (karya tulis ilmiah, membuat alat peraga, alat pelajaran, karya teknologi/seni) dengan 4 angka kredit.

3. III/c ke III/d wajib melaksanakan kegiatan pengembangan diri (pelatihan dan kegiatan kolektif guru) yang besarnya 3 angka kredit dan publikasi ilmiah/karya inovatif (karya tulis ilmiah, membuat alat peraga, alat pelajaran, karya teknologi/seni) dengan 6 angka kredit.

4. III/d ke IV/a wajib melaksanakan kegiatan pengembangan diri (pelatihan dan kegiatan kolektif guru) yang besarnya 4 angka kredit dan publikasi ilmiah/karya inovatif (karya tulis ilmiah, membuat alat peraga, alatpelajaran, karya teknologi/seni) dengan 8 angka kredit.Permasalahannya,mungkin di lapangan kita akan dihadapkan pada pertanyaan seperti ini: (1) Upaya apa yang dilakukan guru untuk meningkatkan profesionalismenya(2) bagaimana mengelola pening-katan profesionalisme guru di sekolah?

Selain itu Sertifikasi guru juga merupakan salah satu upaya pemerintah dalam meningkatkan kualitas guru sehingga pembelajaran di sekolah menjadi berkualitas. Peningkatan program lain yaitu; peningkatan kualifikasi akademik guru, peningkatan kompetensi guru, pembinaan karir guru, pemberian tunjangan guru, pemberian maslahat tambahan, penghargaan, dan perlindungan guru.

Selain hal-hal tersebut di atas secara garis besar juga terdapat beberapa kelompok kekurangan yang terjadi yang menyebabkan guru tidak lulus sertifikasi yang antara lain adalah pada kelompok penelitian dan karya ilmiah serta karya lainnya seperti buku ajar yang disusun sendiri oleh guru. Dalam pelaksanaan PKB hampir tidak pernahguru meneliti bidang pekerjaannya sendiri. Selain itu juga keaktifan dalam mengikuti PKB juga berbagai kegiatan penelitian atau karya ilmiah dan sejenisnya yang sangat kurang .

Berdasarkan pada kenyataan di atas dirasa perlu kiranya memberikan pelatihan pada guru dalam kaitannya dengan PKB yang merupakan sebagai pengembangan profesi guru.

\section{B. Perumusan Masalah}

Berdasarkan analisis situasi tersebut diatas maka dapat dirumuskan sebagai berikut:

1. Apakah dengan mengikuti pelatihan pengembangan keprofesian berkelanjutan (PKB) guru mampuh membuat karya ilmiah?

2. Apakah dengan mengikuti pelatihan guru terampil menulis karya ilmiah.

\section{TINJAUAN PUSTAKA \\ A. Pengembangan Keprofesian Berkelanjutan (PKB)}

Secara etimologis, profesi berasal dari bahasa Inggris profession, bahasa latin profesus, yang berarti mampu atau ahli dalam suatu bentuk pekerjaan (Sanusi, 1991:18). Sedangkan menurut Cogan dalam Peter Jarwis, 1983: 21, disebutkan bahwa profesi adalah suatu keterampilan yang dalam prakteknya didasarkan atas suatu struktur teoritis tertentu dari beberapa bagian pelajaran atau ilmu pengetahuan. Selanjutnya, profesi disebut juga sebagai suatu pekerjaan yang didasarkan atas studi intelektual dan latihan yang khusus, tujuannya untuk menyediakan pelayanan keterampilan atau advis terhadap yang orang lain dengan bayaran atau upah tertentu (Vollmer \& Mills dalam Peter Jarvis, 1983: 21). Sedangkan secara etimologi profesi diartikan suatu pekerjaan yang memper- 
syaratkan pendidikan tinggi bagi pelakunya dengan titik tekan pada pekerjaan mental, bukan pekerjaan manual. Kemampuan mental yang dimaksudkan adalah ada persyaratan pengetahuan teoritis sebagai instrumen untuk perbuatan praktis Pemerintah secara resmi telah mencanangkan bahwa profesi guru disejajarkan dengan profesi lainnya sebagai tenaga profesional. Pencanangan ini ditandai dengan undang-undang Guru dan dosen yang dikeluarkan pada tahun 2005. Harapkan pemerintah dapat meningkatkan kualitas pendidikan, karena guru sebagai pelaksana pada pembelajaran berperan penting dalam kpeningkatan proses pembelajaran di dalam kelas yang akan berujung pada peningkatan mutu pendidikan. Pengakuan kedudukan guru sebagai tenaga profesional dibuktikan dengan sebuah sertifikat profesi guru yang diperoleh melalui uji sertifikasi. Sertifikat pendidik diberikan kepada guru yang telah memenuhi persyaratan sebagai guru profesional. Pengertian dari Pengembangan Keprofesi-an Berkelanjutan (PKB) bagi guru merupakan perubahan secara sadar akan pengetahuan dan peningkatan kompetensi guru sepanjang kehidupan kerjanya dan dilaksanakan secara terus menerus untuk mewujudkan guru profesional, bermartabatdansejahtera. Ada dua macam tujuan dilaksanakannya pengembangan keprofesi-an berkelanjutan (PKB) bagi guru yaitu :

\section{Tujuan Secara UmumPengembang-an Keprofesian Berkelanjutan}

Pengembangan Keprofesian Berkelanjutan bertujuan untuk meningkatkan layanan pendidikan di sekolah dalam rangka meningkatkan mutu pendidikan. Melalui PKB guru diharapkan selalu meningkat kompetensinya, baik dalam penguasaan materi pembelajaran maupun metode yang tepat pada saat melakukan pembelajaran sehingga peserta didik memahami, menyenangi, berperan aktif dalam pembelajaran. Jika pelayanan terhadap peserta didik dapat dioptimalkan diharapkan proses belajar mengajar berjalan dengan baik dan dapat meningkatkan mutu serta hasil belajar yang pada akhirnya mutu pendidikan akan semakin baik. pengembangan keprofesian berkelanjutan (PKB) adalah untuk meningkatkan kualitas layanan pendidikan di sekolah/madrasah dalam rangka meningkatkan mutu pendidikan.

\section{Tujuan secara khususPengembangan Keprofesian Berkelanjutan}

Tujuan pengembangan keprofesian berkelanjutan adalah sebagai berikut;

a. Meningkatkan kompetensi guru untuk mencapai standar kompetensi yang ditetapkan dalam peraturan perundangan yang berlaku.

b. Memutakhirkan kompetensi guru untuk memenuhi kebutuhan guru dalam perkembangan ilmu pengetahuan, teknologi dan seni untuk memfasilitasi proses pembelajaran peserta didik.

c. Meningkatkan komitmen guru dalam melaksanakan tugas pokok dan fungsinya sebagai tenaga profesional.

d. Menumbuhkan rasa cinta dan bangga sebagai penyandang profesi guru.

e. Meningkatkan citra, harkat, dan martabat profesi guru di masyarakat.

f. Menunjang pengembangan karir guru

Secara khusus dilaksanakannya Pengembangan Keprofesian Berkelanjutan bagi Guru adalah untuk memfasilitasi guru dalam mencapai standar kompetensi yang ditetapkan. memotivasi guru untuk tetap memiliki komitmen melaksanakan tugas pokok dan fungsinya sebagai tenaga profesional. Mengangkat citra, harkat, dan martabat profesi guru, rasa hormat dan kebanggaan sebagai guru yang profesional.

\section{Jenis-jenis Pengembangan Kepro- fesian Berkelanjutan (PKB) bagi Guru:}

a. Pengembangan Diri yaitu usaha peningkatan kemampuan kompetensi guru itu sendiri dengan cara mengikuti Diklat fungsional, workshop-workshop 
pendidikan, seminar tentang kependidikan, dan mengikuti Musyawarah Guru Mata Pelajaran (MGMP) sesuai dengan mata pelajaran yang diampunya, serta melakukan kegiatan kolektif guru lainnya.

b. Publikasi Ilmiah yaitu dengan menyusun Karya ilmiah dan mempulikasikannya karya-karya ilmiah atas hasil penelitian maupun gagasan ilmu dibidangnya. Publikasi ilmiah dapat dilakukan dengan presentasi pada forum ilmiah.

c. Karya Inovatif yaitu dengan melakukan kegiatan-kegiatan dalam upaya meningkatkan kompetensi keprofesiannya seperti: menemukan teknologi tepat guna dan membuat atau memodifikasi alat pelajaran dan alat peraga yang sesuai dengan mata pelajaran yang diampunya.

Sebelum melaksanakan Pengembangan Keprofesian Berkelanjutan (PKB) bagi Guru, hal-hal yang dilakukan adalah dengan melakukan Evaluasi Diri (Evadir) dan dari hasil evadir maka kita dapat menentukan langkah dan jenis kegiatan selanjutnya sehingga Jenis pengembangan yang akan dipilih tepat sesuai yang diharapkan sehingga pencapaian kompetensi guru dapat tercapai.

\section{Manfaat Pengembangan Keprofesi-an Berkelanjutan (PKB)}

Manfaat pengembangan keprofesian berkelanjutan yang terstruktur, sistematik dan memenuhi kebutuhan peningkatan keprofesian guru adalah sebagai berikut:

a. Bagi Peserta Didik. Dengan adanya pelaksanaan $\mathrm{PKB}$, maka peserta didik memperoleh jaminan pe-layanan dan pengalaman belajar yang efektif.

b. Bagi Guru. Kepada guru dengan melaksanakan PKB (pengem-bangan keprofesian berkelanjutan) akan dapat memenuhi standar dan mengembangkan kompetensinya sehingga mampu melaksanakan tugas-tugas utamanya secara efektif sesuai dengan kebutuhan belajar peserta didik untuk menghadapi kehidupan di masa datang.

c. Bagi Sekolah/Madrasah akan mampu memberikan pelayanan pendidikan yang lebih baik dan berkualitas bagi peserta didik.

d. Orang tua/masyarakat memperoleh jaminan bahwa anak mereka mendapatkan layanan pendidikan yang berkualitas dan pengalaman belajar yang efektif.

e. Bagi Pemerinta, dengan adanya PKB akan memberikan jaminan kepada masyarakat tentang layanan pendidikan yang berkualitas dan profesional.

\section{Sasaran Pengembangan Keprofesian Berkelanjutan (PKB)}

Sasaran kegiatan pengembangan keprofesian berkelanjutan adalah semua guru pada satuan pendidikan yang berada di lingkungan Kementerian Pendidikan dan Kebudayaan, Kementerian Agama, dan/atau Kementerian lain, serta satuan pendidikan yang diselenggarakan oleh masyarakat. Demikian ulasan tentang pengembangan keprofesian berkelanjutan (PKB) mengenai tujuan, sasaran dan manfaatnya, yang ditulis berdasarkan buku 1 pedoman pengelolaan pengembangan keprofesian berkelanjutan: Pembinaan Pengembangan Profesi Guru yang diterbitkan oleh Pusat Pengembangan Profesi Pendidik, Badan pengembangan Sumber Daya Manusia Pendidikan dan Kebudayaan dan Penjaminan Mutu Pendidian Kementerian Pendidikan dan Kebudayaan tahun 2012.

Pekerjaan profeisonal dapat dikelompokkan ke dalam dua katagori: yaitu Hard Profession dan Soft Profession. Suatu pekerjaan dapat dapat dikatagorikan sebagai Hard Profession apabila pekerjaan tersebut dapat didetailkan dalam perilaku dan langkah- 
langkah yang jelas dan yang relatif pasti. Pendidikan yang diperlukan bagi profesi ini adalah menghasilkan keluaran pendidikan yang dapat distandarisasikan. Artinya, kualifikasi lulusan jelas dan seragam di manapun pendidikan itu berlangsung. Dengan kulifikasi ini seseorang sudah mampu dan akan terus mampu melaksanakan tugas profesinya secara mandiri tanpa pendidikan lagi. Pekerjaan dokter dan pilot sebagai contohnya. Sebaliknya katagori Soft Profession adalah diperlukannya kadar seni dalam melasanakaan pekerjaan tersebut. Ciri pekerjaan tersebut tidak dapat dijabarkan secara detail dan pasti. Sebab, langkah-langkah dan tindakan yang harus diambil, sangat ditentukan oleh kondisi dan stuasi tertentu. Implikasi katagori Soft Profession tidak menuntut pendidikan yang dapat menghasilkan lulusan dengan standar tertentu melainkan menuntut lulusan dibekali dengan kemampuan minimal. Kemampuan ini dari waktu ke waktu harus ditingkatkan agar dapat melaksanakan tugas pekerjaannya sesuai dengan perkembangan masyarakat. Oleh karena itu, lembaga in - service training bagi Soft Profession amat penting. Profesi Guru termasuk dalam katagori Soft Profession. Sehingga dirasakan perlu atau secara rasonal dapat kiranya program sertifikasi guru ini dibenarkan. Karena dengan program sertifikasi ini akan membawa kepada mutu pendidikan yang lebih baik.

Sertifikasi guru merupakan salah satu upaya pemerintah dalam meningkatkan kualitas guru sehingga pembelajaran di sekolah menjadi berkualitas. Peningkatan program lain yaitu; peningkatan kualifikasi akademik guru menjadi S1/D4, peningkatan kompetensi guru, pembinaan karir guru, pemberian tunjangan guru, pemberian maslahat tambahan, penghargaan, dan perlindungan guru.Tugas seorang guru dilihat dari profesi adalah : a) Mendidik : Meneruskan dan mengem-bangkan nilai-nilai hidup. b) Mengajar : Meneruskan dan mengembangkan iptek. c) Melatih : Mengembangkan keterampilan dan penerapannya. Sementara tugas seorang guru sebagai tugas kemanusiaan adalah: a) Menjadi orang tua kedua, b) Transformasi diri, dan c) Autoidentifikasi. Guru juga mengemban tugas kemasya-rakatan yang antara lain: Mendidik dan mengajar masyarakat untuk menjadi WNI yang bermoral Pancasila, dan Mencerdaskan bangsa Indonesia

Guru profesional dan bermartabat menjadi impian kita semua karena akan melahirkan anak bangsa yang cerdas, kritis, inovatif, demokratis, dan berakhlak. Guru profesional dan bermartabat memberikan teladan bagi terbentuknya kualitas sumber daya manusia yang kuat. Sertifikasi guru mendulang harapan agar terwujudnya impian tersebut. Perwujudan impian ini tidak seperti membalik talapak tangan. Karena itu, perlu kerja keras dan sinergi dari semua pihak yakni, pemerintah pusat, pemerintah daerah, mas yarakat, dan guru.

Didalam undang-undang guru dan dosen dinyatakan ada empat kompetensi profesi guru yaitu: 1. Kompetensi Pedagogik, Kemampuan mengelola pembelajaran peserta didik. 2 . Kompetensi Kepribadian, Kemampuan kepribadian yang mantap,berakhlak mulia, arif dan berwibawa serta menjadi teladan peserta didik. 3. Kompetensi Profesional, Kemampuan penguasaan materi pelajaran secara luas dan mendalam. dan 4. Kompetensi Sosial, Kemampuan untuk berkomunikasi dan berinteraksi secara efektif dan efisien dengan peserta didik, sesama guru, orangtua/wali dan masyarakat sekitar. Keempat komponen kompetensi guru ini dijabarkan ke dalam 10 kompetensi.

Selain hal tersebut di atas kita juga mengenal 10 kompetensi guru yaitu: 1) Menguasai bahan pelajaran, 2) Mengelola PBM, 3) Mengelola Kelas, 4) Menggunakan media/sumber belajar, 5) Mengguasai landasan pendidikan, 6) Mengelola interaksi belajar mengajar, 7) Menilai prestasi siswa, 8) Mengenal layanan BK, 9) Mengenal Penyelenggaraan. Administrasi Sekolah, dan 10) Memahami prinsip-prinsip Penelitian Pendidikan.

Sertifikasi guru melalui uji kompetensi memperhitungkan pengalaman profesionalitas 
guru, melalui penilaian portofolio guru. Sepuluh komponen portofolio guru akan dinilai oleh perguruan tinggi penyelenggara sertifikasi guru.

\section{METODE KEGIATAN}

\section{A. Tujuan Kegiatan}

Adapun Tujuan kegiatan ini adalah sebagai berikut :

1. Meningkatkan kompetensi guru untuk mencapai standar kompetensi yang ditetapkan dalam peraturan perundangan yang berlaku.

2. Memutakhirkan kompetensi guru untuk memenuhi kebutuhan guru dalam perkembangan ilmu pengetahuan, teknologi dan seni untuk memfasilitasi proses pembelajaran peserta didik.

3. Meningkatkan komitmen guru dalam melaksanakan tugas pokok dan fungsinya sebagai tenaga profesional.

4. Menumbuhkan rasa cinta dan bangga sebagai penyandang profesi guru.

5. Meningkatkan citra, harkat, dan martabat profesi guru di masyarakat.

6. Menunjang pengembangan karir guru

\section{B. Manfaat Kegiatan}

Banyak manfaat yang dapat diperoleh dari kegiatan ini yaitu antara lain:

1. Bagi Peserta Didik. Dengan adanya pelaksanaan $\mathrm{PKB}$, maka peserta didik memperoleh jaminan pelayanan dan pengalaman belajar yang efektif.

2. Bagi Guru. Kepada guru dengan melaksanakan PKB (pengembangan keprofesian berkelanjutan) akan dapat memenuhi standar dan mengembangkan kompetensinya sehingga mampu melaksanakan tugas-tugas utamanya secara efektif sesuai dengan kebutuhan belajar peserta didik untuk menghadapi kehidupan di masa datang.
3. Bagi Sekolah/Madrasah akan mampu mem-berikan pelayanan pendidikan yang lebih baik dan berkualitas bagi peserta didik.

4. Orang tua/masyarakat memperoleh jaminan bahwa anak mereka mendapatkan layanan pendidikan yang berkualitas dan pengalaman belajar yang efektif.

5. Bagi Pemerinta, dengan adanya PKB akan memberikan jaminan kepada masyarakat tentang layanan pendidikan yang berkualitas dan profesional.

\section{Khalayak Sasaran}

Guru-guru yang akan membuat pengembangan keprofesian berkelanjutan (PKB) dalam rangka mengusulkan naik pangkat

\section{Metode Penerapan Ipteks}

Pada pelatihan ini direncanakan pelaksanaannya sebanyak 4 latihan pertemuan yang masing-masing selama 2 jam. Pada pertemuan pertama diberikan secara umum tentang pengembangan keprofesian berkelanjutan (PKB) dalam rangka mengusulkan naik pangkat

Pada pertemuan 2 sampai ke 4 latihan penerapan pembuatan proposal karya ilmiah dan pertemuan terakhir program kegiatan di adakan evaluasi.

\section{E. Keterkaitan}

Kegiatan yang akan dilaksanakan ini mempunyai keterkaitan dengan berbagai institusi, yang antara lain adalah institusi/dinas pendidikan pada umumnya dan pendidikan menengah, baikbidang sekolah menengah kejuruan maupun umum di wilayah Jakarta Timur. 


\section{HASIL DAN PEMBAHASAN}

\section{A. Hasil Pelatihan}

\section{Evaluasi Umum}

Evaluasi secara umum dalam kegiatan dilakukan tidak saja di akhir dari program pelatihan juga selama proses dilakukan juga evaluasi pada peserta pelatihan. Jadi di awal program diberikan tes awal, di sepanjang pelatihan ada kuis tiap bahasan, dan diakhir program juga ada tes akhir. Serta juga hasil pekerjaan dalam bentuk karya ilmiah.

Dari hasil observasi selama pelatihan berlangsung memperlihatkan keseriusan dan keantusiasan peserta sehingga interaktif berjalan secara hidup, dan produk yang dihasilkan pun baik dalam bentuk karya ilmiah singkat.

\section{Pembahasan Kegiatan}

Hasil kegiatan pengabdian ke pada masyarakat dalam bentukPelatihan Pengembangan Kepofesian Berkelanjutan bagi guru-guru sangat bermanfaat. Adapun manfaat yang dapat diperoleh dari kegiatan ini sbb: (a) guru dapat memperkaya pengembangan keprofesian berkelanjutan (PKB). (b) Pengembangan Keprofesian Berkelanjutan bertujuan untuk meningkatkan layanan pendidikan di sekolah dalam rangka meningkatkan mutu pendidikan (c) Mempercepat proses pembuatan karya tulis ilmiah dalam pengembangan profesi bagi guru. (d) Guru mempunyai keterampilan dalam membuat karya tulis ilmiah berdasarkan pada pengembangan profesi guru. (e) Dapat meningkatkan kualitas penulisan ilmiah sebagai bahan untuk mempersiapakan kenaikan pangkatnya.

\section{Observasi Kegiatan}

Pada kegiatan ini diadakan Observasi terhadap peserta dan evaluasi terhadap program kegiatan. Evaluasi terhadap peserta dilakukan oleh anggota tim dengan membuktikan setiap peserta telah membuat suatu karya ilmiahdalam proses dan hasil yang dicapai secara obyektif.
Evaluasi program kegiatan dilakukan oleh pelaksana untuk mengetahui tingkat ketercapaian tujuan kegiatan yang dilaksanakan. Kegiatan evaluasi dilaksanakan sebelum, selama, dan sesudah kegiatan pelatihan ini berlangsung. Evaluasi sebelum kegiatan dilaksanakan dengan cara diskusi sebelum pemaparan materi; sedangkan evaluasi selama kegiatan berlangsung dilakukan dengan mengamati peserta pelatihan.

Setelah itu, dilakukan evaluasi dengan cara para peserta pelatihan membuat masingmasing bentuk pengembangan keprofesian berkelanjutan dalam bentuk karya ilmiah, jurnal, makalah atau proposal penelitian tindakan kelas yang akan diajukan pada penelitiannya untuk melihat keberhasilan pelatihan.

\section{B. Hasil Kegiatan}

Berdasarkan hasil pelatihan didapatkan suatu perubahan yang baik bagi para peserta. Yang dahulu sebelumnya belum terbuka wawasannya mengenai pengembangan ke profesian berkelanjutan, sekarang memiliki kemampuan untuk membuat atau menulis sebuah karya ilmiah, jurnal, makalah atau proposal penelitian tindakan kelas. Hal ini mengindikasikan bahwa pelatihan yang diadakan sudah berhasil.

Kemudian dari karya ilmiah yang diajukan dan dibuat oleh para peserta pelatihan, mengindikasikan bahwa wawasan mengenai masalah-masalah di dalam proses pembelajaran yang sering mereka alami, sudah bisa di perbaiki menjadi sebuah karya ilmiah, jurnal dan hasil penelitian. Sehingga bisa dikatakan bahwa pelatihan pengembangan keprofesian berkelanjutan (PKB) ini sudah berhasil dengan baik.

\section{Faktor Pendorong dan Penghambat}

Faktor pendorong kegiatan ini adalah kesungguhan peserta, kesungguhan dari para Kepala Sekolah, dan juga pihak terkait yang memprakarsai kegiatan dan membantu menyediaan akomodasi untuk kelancaran 
pelatihan guru-guru, serta izin yang dibantu pihak yang berwenang, dan prasarana yang telah diberikan oleh LPM UNJ.

Semuanya telah menjadikan kegiatan pengabdian ini berjalan sesuai dengan jadwal yang telah ditentukan. Adapun faktor penghambat pelatihan ini dapat dikatakan tidak ada, hanya faktor dana yang terbatas, sehingga kegiatan ini hanya memberikan sarana yang terbatas pula, baik kepada peserta pelatihan maupun kepada pelatihnya sendiri.

\section{KESIMPULAN DAN SARAN}

\section{A. Kesimpulan}

Berdasarkan hasil pelatihan yang dilakukan, didapatkan beberapa kesim-pulan. Antara lain:

(a) guru dapat memperkaya pengembangan keprofesian berkelanjutan (PKB). (b) guru dapat mengetahui bagaimana pelaksanaan pengembangan keprofesian berkelanjutan bertujuan untuk meningkatkan layanan pendidikan di sekolah dalam rangka meningkatkan mutu pendidikan (c) guru dapat mempercepat proses pembuatan karya tulis ilmiah dalam pengembangan profesi bagi guru. (d) guuru menjadi punyai keterampilan dalam membuat karya tulis ilmiah berdasarkan pada pengembangan profesi guru. (e) guru dapat meningkatkan kualitas penulisan ilmiah sebagai bahan untuk mempersiapakan kenaikan pangkatnya.

\section{B. Saran}

Dalam Pelaksanaan pelatihan disarankan, antara lain:

1. Para peserta berkeinginan untuk pelatihan ini berlanjut ke penulisan jurnal ilmiah.

2. Para peserta mengharapkan bimbingan berkelanjutan dalam bentuk pembimbingan terstruktur dalam penulisan karya ilmiah oleh LPM UNJ.

3. Waktu pelatihan yang terbatas karena mencoba memenuhi kebutuhan perserta tersebut, ada baiknya pada pelatihan selanjutnya berlatih membuat tulisan ilmiah, membuat makalah, jurnal dan proposal mengenai PTK,

4. Dengan sarana, prasana dan pendanaan yang terbatas menyebabkan pada proses pelaksanaan pelatihan ini mengalami sedikit permasalah, namun secara keseluruhan proses pelatihan ini termasuk berhasil dan sukses.

\section{DAFTAR PUSTAKA}

[1] APA, 1983. Publication Manual of the American Psychological Association Third Edition. Washington DC: American Psychological Association.

[2] Barlow, Daniel Lenox. 1985. Educational Psychology: The Teaching LearningProcees. Chiocago: The Moody Bible Institute.

[3] Hopkins, D. 1985. A Teacher"s. Guide to Classroom Research. Philadelphia: Open University Press.

[4] Suwarsih Madya. 2006. Teori dan Praktik Penelitian Tindakan. Bandung: Alfabeta.

[5] Syarfrudin Nurdin, 2005, Guru profesional dan implementasi Kurikulum Quantum Teaching, Ciputat Jakarta 